\title{
The Utilization of Village Funds and Its Correlation on Health Development at Village Level in Kebumen Regency in 2015-2018
}

\author{
Nadilah Salma ${ }^{1}$, Ede Surya Darmawan ${ }^{1 *}$ \\ ${ }^{1}$ Department of Health Policy and Administration Faculty of Public Health, Universitas Indonesia, Depok, Indonesia \\ ${ }^{*}$ Corresponding author. Email: edesurya@ui.ac.id
}

\begin{abstract}
Background: Nowadays, a village is not just become an object of development but the subject behind it with its real autonomy avowed by formal regulatory framework (Village Law (Law No. 6 Year 2014 about Village)). A village also receives additional income in the form of village funds which potentially becomes new source to rural health development financing. Objective: This research shows the use of village funds and its correlation with rural health development at villages in Kebumen Regency for four years. Method: This is a quantitative research with survey method and use data of realization of village funds and health development achievements in Kebumen Regency. Result: Utilization of village funds for health sector took about 3.44-5.92\% proportion and relatively small per capita amount around 3,655-16,879 rupiahs. The largest expenditure allocation tends to be infrastructure facilities for village health services and environmental health in the form of latrines/toilets and clean water facilities. In addition, there is low correlation between the use of village funds for health and access to clean water, access to proper latrines/toilets, an increase in "Posyandu Aktif", and "Desa Siaga Aktif" status. As a recommendation, government needs to establish indicators that can measure health development at village level.
\end{abstract}

Keywords: village funds, health development, village law, health financing

\section{INTRODUCTION}

A village is a place where people live, get to know one another, live in harmony, agree with the agreement and relationship of the socio-cultural value system, and have their own procedures for community management [1]. The existence of villages before Indonesia state established and it has developed until $90 \%$ of the territory in Indonesia. Regarding the village, it starts with the self-government of the community which is identical to the village community which is determined based on agreement not direction or intervention from any parties. Then, the position of the village in the government system changes through regime change and makes the village far from independence and sustainability, so that various problems such as poverty and other backwardness are inevitable.

Various programs and projects have intervened in many villages, but the impact of progress can be said to be slow. Apart from the fact that villages are still merely objects of development, development from existing supra-village level is still discriminatory. Not all villages experience village development programs and projects, in 2008 only
$31 \%$ of the villages [2]. Even large programs such as the Program Nasional Pemberdayaan Masyarakat/PNPM (National Community Empowerment Program) which within 5 years were only able to cover $54 \%$ of the villages [3]. In addition, another issue is that national development funds often do not reach the village level. Nearly half of total regional income is used for wages and the rest is for functions that have been blocked by the budget such as education and other matters such as Standar Pelayanan Minimal/SPM (Minimum Service Standards) and infrastructure development [4]. If it is considered from the escalation of health financing needs due to the demographic and epidemiological transition it is also a joint challenge. As Agusta's [3] research (2014) projected the transformation of villages in 2003 - 2035 that villagers will increase rapidly, one of the consequences is that the pattern of health services will be more focused on rural areas. If it only relies on regions with limited regional fiscal capacity and faced with the current system condition, it seems quite hard.

Now with all policies that support village development which leads to the goal of village independence, village is a 
strategic position as the basis of change and has the potential to provide improvements to national development. The issuance of the Village Law brought two main substances that gave the village strength, namely the village regaining its original autonomy and additional funds to exercise its authority. The granting of village funds aims to improve the welfare of the community and equitable development of villages. To achieve this goal, its use is prioritized for the development and empowerment of rural communities.

The health sector falls within the scope of these priorities so that village funds are additional potential resources for health development activities in the village. If the potential is able to be maximized it will be able to improve community health at the village. The success of health development in the village through Upaya Kesehatan Berbasis Masyarakat/UKBM (Community-Based Health Efforts) certainly helped increase Gerakan Masyarakat Hidup Sehat/ Germas (Community Healthy Life Movement) supported the achievement of the Regional SPM, and led to the achievement of Program Indonesia Sehat-Pendekatan Keluarga/PIS-PK (Healthy Indonesia Program with the Family Approach). Therefore, village as a place where the community (family) lives is a domain of health development that is included in the target and place of implementing these programs.

However, it is not yet known how the use of village funds in the health sector and their correlation with health development at the village level and this research was conducted to answer this. Kebumen Regency was chosen as the location under study because it was the largest village recipient regency in the province which also received the largest village fund in Indonesia, Central Java [5]. In addition, the number of villages was also large so that it was assumed there would be several variations of utilization as well.

\section{METHOD}

This research is quantitative research with survey method and uses data on the realization of the utilization of village funds and data on health development achievements in Kebumen Regency. The health account approach is used to illustrate the utilization of village funds for the health sector including expenditure allocation based on the type of activity and budget line. The study also looked at the correlation of utilization of village funds in the health sector with the achievements of health development at the village level which included population access to healthy latrines/toilets, access to safe drinking water, percentage of Posyandu aktif (Active Integrated Health Service Post), and Desa Siaga Aktif status (the "allert village": provision of basic health services at village level, and the surveillance of communicable disease, monitoring of lifestyle activities and disaster preparedness).

The population in this study were all villages in Kebumen Regency, which totaled 449 villages. Then 96 villages were included as research samples that fit the inclusion and exclusion criteria. Inclusion criteria were villages that received village funds, routinely allocated village funds to the health sector each year, and there were reports, while the exclusion criteria were villages whose data were incomplete on one or more variables.

\section{RESULTS AND DISCUSSION}

Result

Health development financing at village level in Kebumen Regency is generally funded by village funds because other sources of funds are limited and already used for other matters. The amount of village funds for Kebumen Regency is quite large, about $350,691,179,000$ rupiahs (in 2018) that means almost three times the village funds obtained in the first year. The amount was then distributed to 449 villages with an average per village ranging from 280 million to 781 million in a period of four years.

Villages that spent village funds in the health sector continue to increase each year. A total of 398 villages out of 446 villages recorded for expenditure (89.2\%) spent village funds in the health sector in 2018. This number increased when compared to 2015 which were only 219 out of 449 villages $(48.8 \%)$. The total allocation of the utilization of village funds for the health sector from the villages reached 4 billion and the trend continues to increase until it reached 20.7 billion in 2018 . Besides the amount, the proportion also increased from $3.44 \%$ to $5.92 \%$.

If the per capita amount is calculated by dividing the total allocation of health expenditure divided by the total population in a particular year, it is obtained as much as $3,655-16,879$ rupiahs. In addition, it was also found that only 158 out of 449 villages $(35 \%)$ or around one third of the total villages consistently budgeted village funds for health spending each year. While other villages only spend on health in certain years, there were even villages that have never allocated village funds for health spending at all.

Table 1. Village Fund Income and General Overview of Village Fund Allocation for Health in Kebumen Regency in $2015-2018$

\begin{tabular}{cccccc}
\hline Year & $\begin{array}{c}\text { Village funds } \\
\text { amount }\end{array}$ & $\begin{array}{c}\text { Total allocation } \\
\text { of village funds } \\
\text { utilization for } \\
\text { health }\end{array}$ & $\%$ & $\begin{array}{c}\text { Per } \\
\text { capita }\end{array}$ \\
\hline $\mathbf{2 0 1 5}$ & $125,844,565,000$ & $4,331,076,998$ & 3.44 & 3,655 \\
\hline $\mathbf{2 0 1 6}$ & $282,401,546,000$ & $11,829,603,711$ & 4.19 & 9,952 \\
\hline $\mathbf{2 0 1 7}$ & $359,998,061,000$ & $19,837,001,145$ & 5.51 & 16,641 \\
\hline $\mathbf{2 0 1 8}$ & $350,691,179.000$ & $20,766.885,489$ & 5.92 & 16,879 \\
\hline
\end{tabular}

It could be concluded that there had been an increase in the number of villages which utilized village funds for the health sector so that the total utilization and per capita size had generally also increased. Furthermore, the expenditure of village funds for the health sector was examined in 96 
villages with complete data and routine allocations. The amount was obtained from the classification of health expenditure items in the report on the overall utilization of village funds. In describing the magnitude, allocation patterns, and details of the utilization of village funds in this study the health account approach was used. This approach has been used in Indonesia at the national scale (National Health Account/NHA) and sub-national
(Provincial Health Account/PHA and District Health Account/DHA) but there is no village scale. Therefore, in this study adjustments were made. The classification of financing components in this study refers to the code and description of activities in the application of the Online Monitoring Sistem Perbendaharaan dan Anggaran Negara/OMSPAN (Online Monitoring system of the Treasury and State Budget).

Table 2. Allocation of Village Funds Based on Budget Line

\begin{tabular}{|c|c|c|c|c|c|c|c|}
\hline \multirow{3}{*}{ Budget line } & \multicolumn{7}{|c|}{ Year } \\
\hline & \multicolumn{2}{|l|}{2015} & \multicolumn{2}{|c|}{2016} & \multicolumn{2}{|l|}{2017} & 2018 \\
\hline & Total & $\%$ & Total & $\%$ & Total & $\%$ & N/A \\
\hline Maintenance & $83,480,500$ & 4.05 & $293,968,950$ & 7.91 & $19,596,000$ & 0.40 & N/A \\
\hline Operations & $300,194,060$ & 14.57 & $860,442,833$ & 23.15 & $1,425,643,880$ & 29.30 & N/A \\
\hline TOTAL & $2,059,917,596$ & 100 & $3,716,570,173$ & 100 & $4,865,328,780$ & 100 & N/A \\
\hline
\end{tabular}

Calculations based on budget lines were only done for 20152017 data because the 2018 data classification was somewhat different (more general) so it was rather difficult to be detailed. The results show that since village funds had been allocated to villages, they had been allocated almost entirely or more than two-third of them for (physical) investment expenditure. The remaining less than one third was divided into operational, maintenance, and other expenses.

If it was viewed based on the type of activity (see table 3), the flow of village funds for the health sector in 2015 was mostly for the construction and maintenance of sanitation facilities in the form of latrines and Mandi Cuci Kakus/MCK (Public bathing, washing, and toilet facilities) which amounted to $33.85 \%$. The same phenomenon also occurred in 2017 and 2018 which reached $39.09 \%$ and $50.79 \%$. Whereas in 2016, the largest proportion was for construction, maintenance and procurement of health service facilities by $27.20 \%$.

\section{Village Funds and Health Development}

Health development variables in this study consisted of the percentage of the population with access to proper latrines, the percentage of population with access to safe drinking water, an increase in Posyandu Aktif [6], and an increase in the status of Desa Siaga Aktif. Presentation of the results of research in this section was in the form of tabulation of health development achievements before and after village funds were available. To see that transformation, 2014 and 2018 data were used for comparison. The average coverage of access to safe drinking water, proper latrines/toilet, and the percentage of Posyandu Aktif in 2014 was already above $70 \%$. All achievements had also increased in 2018 although there was still a considerable gap between the lowest and highest values.

Broadly, more than half of the total amount of village funds for the health sector tended to be allocated to environmental sanitation activities. Even though the total expenditure items were far less than for health service activities and community empowerment. That means environmental sanitation activities took up more funds because of their physical development ones.

For the achievement of Desa Siaga Aktif status, it could be seen from the status of its development which consists of 4 levels [7]. In 2014, Desa Siaga Aktif status was dominated by Madya Level (level 2) and Purnama Level (level 3). Then, in 2018, there was an increase to Mandiri Level (level $4 /$ the highest) for 12 villages. 
Table 3. Allocation of Village Funds Based on Type of Activity

\begin{tabular}{|c|c|c|c|c|c|c|c|c|}
\hline \multirow{2}{*}{ Type of activity } & \multicolumn{8}{|c|}{ Amount (n)* and percentage (\%) } \\
\hline & n (2015) & $\%$ & n (2016) & $\%$ & n (2017) & $\%$ & n (2018) & $\%$ \\
\hline \multicolumn{9}{|l|}{ Basic Health Services and Community Empowerment } \\
\hline Organizing Posyandu & 141,850 & 6.89 & 590,613 & 15.89 & 964,924 & 19.83 & 775,712 & 15.39 \\
\hline Organizing Poskesdes $* * /$ Polindes $* * *$ & - & - & 27,196 & 0.73 & 98,098 & 2.02 & 114,282 & 2.27 \\
\hline Organizing Desa Siaga Aktif & 21,546 & 1.05 & 33,296 & 0.90 & 182,295 & 3.75 & 231,510 & 4.59 \\
\hline $\begin{array}{l}\text { Health promotion/disease prevention/health sector } \\
\text { training }\end{array}$ & 116,121 & 5.64 & 196,930 & 5.30 & 231,856 & 4.77 & 130,355 & 2.59 \\
\hline Services and efforts to improve family planning & 7,285 & 0.35 & 3,838 & 0.10 & 14,609 & 0.30 & - & - \\
\hline Examination and treatment & - & - & 6,098 & 0.16 & 16,150 & 0.33 & - & - \\
\hline Health funding assistance & 4,685 & 0.23 & 500 & 0.01 & - & - & - & - \\
\hline $\begin{array}{l}\text { Construction/ rehabilitation/ maintenance/ } \\
\text { procurement of Posyandu/Polindes/Poskesdes } \\
\text { infrastructure facilities }\end{array}$ & 488,883 & 23.73 & $1,010,956$ & 27.20 & 724,313 & 14.89 & 706,764 & 14.02 \\
\hline Others UKBM & 13,390 & 0.65 & 2,470 & 0.07 & 23,570 & 0.48 & 9,354 & 0.19 \\
\hline \multicolumn{9}{|l|}{ Environmental Sanitation } \\
\hline $\begin{array}{l}\text { Construction/ rehabilitation/ maintenance/ } \\
\text { improvement of latrines/ MCK facilities }\end{array}$ & 697,271 & 33.85 & 926,920 & 24.94 & $1,901,835$ & 39.09 & $2,560,520$ & 50.79 \\
\hline Construction/ maintenance of village water sources & 501,959 & 24.37 & 917,749 & 24.69 & 596,154 & 12.25 & 253,491 & 5.03 \\
\hline $\begin{array}{l}\text { Construction/maintenance of clean water connections } \\
\text { to household }\end{array}$ & 42,972 & 2.09 & - & - & - & - & 244,134 & 4.84 \\
\hline $\begin{array}{l}\text { Maintenance of other environmental sanitation/ } \\
\text { sewerage (SPAL) works }\end{array}$ & 23,950 & 1.16 & - & - & 111,519 & 2.29 & 14,999 & 0.30 \\
\hline TOTAL & $2,059,917$ & 100 & $3,716,570$ & 100 & $4,865,328$ & 100 & $5,041,124$ & 100 \\
\hline
\end{tabular}

The increase in the variable access to proper latrines and access to safe drinking water was categorized to be low, high, and no increase. The cut-off point based on a median, $7.29 \%$ for the variable access to proper latrines and $6.5 \%$ for the variable access to safe drinking water. Within a period of 4 years, villages tended to increase in terms of population access to proper latrines (78 villages) and population access to safe drinking water (68 villages). While the increasing trend did not occur in the status of Desa Siaga Aktif and Posyandu Aktif. The number of villages that did not increase was more dominant.

Table 4. Improvement of Health Development Achievement in Kebumen District in 2014 and 2018

\begin{tabular}{lcc}
\hline & $\begin{array}{c}\text { Number of } \\
\text { Village }\end{array}$ & $\%$ \\
\hline Residents with improved latrine access & 30 & 31.25 \\
Low & 48 & $50, .00$ \\
High & 18 & 18.75 \\
Not increased & 20 & 20.83 \\
\hline Residents with access to safe drinking water & 48 & 50.00 \\
Low & 28 & 29.17 \\
High & & \\
Not increased & 17 & 17.71 \\
\hline Posyandu Aktif percentage & 79 & 82.29 \\
Increased & \multicolumn{3}{|c}{} \\
Not increased & 33 & 34.38 \\
\hline Desa Siaga Aktif status & 63 & 65.62 \\
Increased &
\end{tabular}

Statistical test results show low correlation between the average proportion of village funding for health and health development variables (access to proper latrines, access to safe drinking water, Posyandu Aktif, and Desa Siaga Aktif status).

\section{Discussion}

In the beginning of the implementation of village funds, the Kebumen regency was dominated by underdeveloped villages, therefore based on the Village Ministerial Regulation about the Priority of Using Village Funds, it was recommended to fulfill basic social service needs including the health sector. However, it was not optimal, as seen from the results of research that the utilization of village funds for the health sector is still small in number and unstable. Another study conducted in two other Regencies, Sampang and Pasuruan, showed an average proportion that was still in the same range of $4.17 \%$ [8]. However, it is still greater because the calculation of health expenditure in that research only covers basic health services in villages such as Posyandu, Poskesdes, Perilaku Hidup Bersih dan Sehat/PHBS (clean and healthy behavior), health education, while environmental sanitation efforts such as the construction of latrines and clean water facilities were not covered.

One way to keep the activities and budget allocation for health spending remains is by earmarking. However, if village funds are earmarked for health spending, that is not the right choice because it is not in line with village autonomy. Earmarking can spoil the village deliberation process because it cuts the budget negotiation process in it. In addition, the general expenditure provisions with no limit or determination for certain allocations, for example, a certain percentage of health, allows the budget maximizer of 
development in the village has not been able to be "captured".

In this study, the average allocation of health expenditure sourced from village funds was correlated with the output of health development in the villages selected based on the slices of several existing health indicators. Because until now, there has not been an indicator to measure the achievement of health development at the village level. The Ministry of Health issued health indicators such as SPM, Indikator Keluarga Sehat/ IKS (Healthy Family Indicators), PHBS, and others. Ministry of Villages, Disadvantaged Regions, and Transmigration also issued Indeks Desa Membangun/IDM (Village Development Index) which included health indicators. For this reason, an indicator that can measure health development appropriately at the village level is needed.

\section{CONCLUSION}

Based on the findings, it can be concluded that the utilization of village funds for the health sector in Kebumen Regency is still small in amount, unstable, and low in correlation to health development at the village level. So that health development at the village level can be maximized, indicators that can measure the achievements of health development at the village level is needed. These indicators must be able to synchronize health development between levels of government by paying attention to the complexity of village development. The principle of sustainable livelihood that is used as an approach in village development can be taken into consideration. In this case, the Ministry of Health, the Ministry of Villages, Disadvantaged Regions, and Transmigration, the Ministry of Home Affairs, the National Development Planning Agency, need to determine these indicators together, agree on them, and set them in the form of joint regulation. The temporary alternative option is that the Sub-National Government (Provincial and Regency) need to translate the Regional Health SPM in the form of regulations that are more focused at the village level by considering the conditions of the villages in the region. Aside from being a standardization of the implementation of health services at the village level, it can also facilitate the determination of funding for health services/activities in the village so that it impacts on the efficiency and maintenance of the allocation of health spending.

\section{REFERENCES}

[1] C. Nurcholis, Pertumbuhan dan penyelenggaraan pemerintahan desa. Jakarta: Erlangga, 2011.

[2] N. Irawan, Tata kelola pemerintahan desa era UU Desa. Jakarta: Yayasan Obor Indonesia, 2017.

[3] I. Agusta, "Transformasi desa Indonesia 2003-2025," 2014. 
[4] P. B. Ali, R. G. M. Siahaan, and Ardhiantie, "Laporan konsolidasi kajian sektor kesehatan 2018,” Jakarta, 2018.

[5] DPR-RI, “Kajian dana desa di Provinsi Jawa Tengah tahun 2015-2017."

[6] R. I. Kementerian Kesehatan, Pedoman Umum Pengelolaan Posyandu. Jakarta, 2011.

[7] R. I. Kementerian Kesehatan, Republik Indonesia Kementerian Dalam Negeri, Pedoman Umum Pengembangan Desa dan Kelurahan Siaga Aktif. 2010.

[8] Tumaji, "Pemanfaatan dana desa untuk pembangunan kesehatan di Kabupaten Pasuruan dan Sampang," Buletin Penelitian Sistem Kesehatan, vol. 21, no. 3, pp. 141-151, 2018 .

[9] C. Cashin, S. Sparkes, and D. Bloom, "Earmarking for Health From Theory to Practice," 2017.

[10] S. Suarsih, D. K. Sunjaya, E. P. Setiawati, and G. Wiwaha, "Analisis Kebijakan Dana Desa untuk Pembangunan Kesehatan di Kabupaten Malinau dengan Pendekatan Segitiga Kebijakan by Triangle Policy Approach," Jurnal Sistem Kesehatan, vol. 2, pp. 211-217, 2017.

[11] D. Dodo, L. Trisnantoro, and S. Riyanto, "Analisis pembiayaan program kesehatan ibu dan anak bersumber pemerintah dengan pendekatan health account," Jurnal Kebijakan Kesehatan Indonesia, vol. 01, no. 01, pp. 13-23, 2012. 